\title{
SECTION 24C: INDICATORS REGARDING THE CERTAINTY OF THE INCURRAL OF FUTURE EXPENDITURE
}

\author{
Lizelle Calitz* \\ Stellenbosch University \\ strauss.lizelle@gmail.com
}

Received: March 2015

\author{
Linda van Zyl* \\ Stellenbosch University \\ Ivschalk@sun.ac.za
}

Accepted: September 2015

\begin{abstract}
Section $24 \mathrm{C}$ of the Income Tax Act No. 58 of 1962 provides for a deduction of future expenditure that will be incurred by the taxpayer in the performance of his obligations under a contract from which the taxpayer derived income. The objective of this article is to compile a list of indicators demonstrating when there will be certainty that future expenditure will be incurred as aforementioned. The conclusion reached is that a definite connection must exist between the incurral of the future expenditure and the obligation to perform under the contract. Further, conditions and warranties are contractual terms that indicate that there is uncertainty regarding the taxpayer's obligations to perform under the contract. A time clause in a contract and a high probability that the taxpayer will perform an unconditional obligation under a contract, however, both indicate that there is certainty regarding the incurral of future expenditure. A contingent liability to pay for future expenditure or if the future expenditure is unquantified are not indicators as to whether there is certainty that the future expenditure will be incurred.
\end{abstract}

Keywords

Section 24C, tax deduction, future expenditure, will be incurred, obligation to perform, contingent liability, probability

*Ms L Calitz was a senior lecturer in the School of Accounting, Stellenbosch University, South Africa.

\#Prof $\mathbf{L}$ van $\mathbf{Z y l}$ is an associate professor in the School of Accounting, Stellenbosch University, South Africa. 


\section{INTRODUCTION}

Section 24C of the Income Tax Act No. 58 of 1962 (South Africa, 1962) (the Act) was introduced into the Act in 1980. According to the Explanatory Memorandum on the Income Tax Bill of 1980 (SARS, 1980) (the Explanatory Memorandum), the purpose of section $24 \mathrm{C}$ is to address situations where income is received or accrued in terms of a contract in one year of assessment, and the income is to be utilised to finance future expenditure in a subsequent year of assessment. The Explanatory Memorandum refers specifically to a situation in the construction industry where a contractor, prior to the commencement of the contract, receives an advance payment to enable him to purchase material and equipment. The result is that such advance payments are included in gross income - in terms of the general definition of gross income - and are subject to taxation in the year of assessment in which they were received, but are not matched by related deductible expenditure in the same year of assessment. The reason for this is that section 11 (a) allows expenditure to be deducted only once it is 'actually incurred', and section 23(e) prohibits the deduction of any accounting provisions by prohibiting the deduction of any income capitalised in any way. Section $24 \mathrm{C}$ was inserted to empower the Commissioner (the Commissioner) of the South African Revenue Service (SARS) to allow a deduction in respect of any amount received under a contract, which will be utilised by the taxpayer to finance future expenditure in the performance of his obligations under that contract.

Tax Court cases on section $24 \mathrm{C}$ underline various interpretation problems, one being to determine when there will be certainty that future expenditure will be incurred by the taxpayer in the performance of his obligation under the contract (ITC 152754 SATC 227; ITC 160158 SATC 172; ITC 166761 SATC 439; ITC 169763 SATC 146; ITC 173965 SATC 43 and Special Board Decision No. 129).

Although there is other literature available on the interpretation of section $24 \mathrm{C}$ (Clegg \& Stretch, 2011; Davis, Olivier \& Urquhart, 2013; De Koker \& Williams, 2011; Meyerowitz, 2008; Stiglingh, Koekemoer, Van Schalkwyk, Wilcocks \& De Swardt, 2014 and Williams, 1997) no specific research has, however, been done to provide indicators that can serve to demonstrate when there will be certainty that future expenditure will be incurred by the taxpayer in the performance of his obligations under the contract.

SARS recently issued Interpretation Note: No. 78, Allowance for future expenditure on contracts (SARS, 2014) (IN 78) to provide guidance on its interpretation and application of section 24C. In IN 78 SARS introduces, inter alia, guidelines to indicate when there will be certainty that expenditure 'will be incurred in a subsequent year of assessment', as required by section $24 C(1)$. IN 78 also addresses the taxpayer's obligations to perform under a contract. This research combines the guidance provided for in IN 78 and the principles from the Tax Court cases on section $24 \mathrm{C}$ in order to determine when there will be certainty that future expenditure will be incurred.

\section{RESEARCH OBJECTIVE, RESEARCH METHODOLOGY, SCOPE AND VALUE OF RESEARCH}

The first objective of this article is to compile from Tax Court cases, authoritative academic literature and IN 78 a list of indicators demonstrating when there is certainty that future expenditure will be incurred by the taxpayer in the performance of his obligations under the contract. 
Achieving this objective requires a brief discussion of the requirements of section $24 C$, as well as a discussion of the meaning of the word 'future' and the phrases 'will be incurred' and 'in the performance of his obligations under the contract' as used in section 24C. This is done in order to answer the following research questions:

- What is the effect of contractual terms on the certainty that future expenditure will be incurred?

- What other circumstances affect the certainty that future expenditure will be incurred?

A second objective is to determine whether the guidance provided in IN 78 relating to the certainty that future expenditure will be incurred by the taxpayer in the performance of his obligations under the contract is in agreement with previous established principles. This is significant because an Interpretation Note is merely SARS's interpretation of a provision in the Act and does not have the force of law (Stiglingh et al., 2014:13). A taxpayer may thus challenge the practice of SARS, as set out in an Interpretation Note, if he disagrees with the interpretation. The guidelines in IN 78 will, therefore, be compared with the rulings in Tax Court cases and other authoritative academic literature in order to highlight any differences or shortcomings.

The research method adopted consists of a literature review of section 24C, Tax Court cases on section 24C, the Explanatory Memorandum, authoritative academic literature and IN 78. In interpreting section 24C, a contextual approach was followed.

The requirements of section $24 \mathrm{C}$ are only briefly discussed to serve as a basis of achieving the objectives of this article. The Law of Contract is not discussed in depth. When references are made to a 'contract' or the 'obligation to perform under the contract', it is assumed that all the requirements for a valid contract have been met. The requirements for a valid contract (an obligatory agreement) are, inter alia, the contractual capacity of the parties, possibility of performance, legality of the agreement and prescribed formalities (Van der Merwe et al., 2007:8).

International legislation, case law and literature will not be consulted and the accounting concepts of 'provisions' and 'contingent liabilities' will be addressed only briefly in order to put the accounting recognition criteria of provisions into perspective.

This article provides clarity regarding the required certainty that future expenditure will be incurred by the taxpayer in the performance of his obligations under the contract. The newly released IN 78 is, for the first time, incorporated in academic research on section 24 C, thereby indicating whether the guidelines provided for by SARS in IN 78 are in agreement with previous established principles or whether new guidelines are introduced. The contribution of this article is to provide updated academic literature relating to the certainty that future expenditure will be incurred.

\section{ACCOUNTING PRACTICE VS. INCOME TAX ACT}

In order to understand the reason why taxpayers are contending to deduct future expenditure for tax purposes, it is useful to briefly discuss the accounting treatment of provisions and contingent liabilities in taxpayers' financial statements.

According to Williams (1997:469), accounting principles and sound business practice require that a taxpayer should set aside, by way of a provision or a suspense account, some of his income earned in the current year that he will use to defray future expenditure which relates to that 
income. Further, IAS 1, Presentation of Financial Statements, requires that the financial statements must 'present fairly' the financial position, financial performance and cash flows of an entity. The accounting standard that regulates the treatment of provisions is IAS 37 Provisions, Contingent Liabilities and Contingent Assets. According to IAS 37 paragraph 10 a 'provision' is a liability of which the amount and the timing of the payment is uncertain. A liability, in its turn, is a present obligation that arises from events in the past of which payment is expected to lead to an outflow of resources (economic benefits). An obligating event is an event that results in a legal or constructive obligation, where the entity has no other realistic alternative but to pay. A provision for the payment of future legal obligations is, therefore, recognised in the financial statements and will affect the net profit of the taxpayer.

A 'contingent liability', for accounting purposes, is a possible obligation arising from events in the past the existence of which is confirmed by occurrence or non-occurrence of one or more uncertain future events outside of the entity's control; or it is a present obligation which arises from events in the past, but is not recognised because the outflow of economic benefits of payment is unlikely; or the amount cannot be measured reliably (IAS 37: paragraph 10). A contingent liability is not recognised in the financial statements for accounting purposes, but is disclosed in the notes to the financial statements.

For accounting purposes, a taxpayer must therefore make provision for present legal obligations to pay future expenditure in order to make sure there is a reserve for future payments. This provision is made even though the amount and the timing of the payment is uncertain. However, according to Olivier (2007:601), when determining whether an amount is taxable or deductible for income tax purposes, the accounting treatment is irrelevant. This was confirmed in Caltex Oil (SA) $L t d v$ Commissioner of Inland Revenue 37 SATC 1, where it was held that the tax laws only allow for the deduction of transactions for which specific provision is made in tax legislation. Section 23(e) of the Act also specifically prohibits a deduction of income carried to any reserve fund or capitalised in any way. It is thus clear that an amount might be recognised as a provision for accounting purposes, but the same amount might not yet meet the requirements of a deductible amount in terms of the Act for tax purposes.

Certain accounting provisions may, however, qualify for deduction in terms of section $24 \mathrm{C}$ if all the requirements of section $24 C$ are met.

\section{REPUIREMENTS OF SECTION $24 C$}

Section $24 C$ consists of three sub-sections. The phrase 'future expenditure' in relation to any year of assessment is defined in section $24 \mathrm{C}(1)$. The expenditure under contention must meet the following requirements:

- There must be an amount of expenditure; and

- The Commissioner must be satisfied that the amount will be incurred after the end of such year of assessment; and

- Such amount will be allowed as a deduction from income in a subsequent year of assessment (section $24 \mathrm{C}(\mathrm{l})(\mathrm{a}))$; or

- Such amount is in respect of the acquisition of any asset in respect of which any deduction will be admissible under the provisions of the Act (section $24 C(1)(b))$. 


\section{Calitz \& Van Zyl}

The requirement that future expenditure must be deductible in terms of a provision in the Act in a subsequent year of assessment indirectly and, inter alia, refers to sections 11 (a) to $11(\mathrm{w})$ of the Act. These sections list deductions that are allowed in determining the taxable income of a taxpayer carrying on a trade. Section $1 \mathrm{l}(\mathrm{x})$ brings within the scope of section 11 all other amounts allowed as deductions from the income of the taxpayer in terms of any other provision in Part I of the Act (Stiglingh et al., 2014:166). Section 11(a) is the so-called general deduction formula and allows for a deduction of expenditure and losses, actually incurred, in the production of the income, provided such expenditure and losses are not of a capital nature. In Port Elizabeth Electric Tramway Co Ltd v Commissioner of Inland Revenue 8 SATC 13 the court specified that sections 11 (a) and $23(\mathrm{~g})$ should be read together. Section $23(\mathrm{~g})$, which prohibits the deduction of expenditure that is not laid out or expended for the purpose of trade must, therefore, also be taken into account when interpreting section $24 \mathrm{C}$. Although the scope of sub-sections $24 \mathrm{C}(\mathrm{l})(\mathrm{a})$ and (b) is very wide, for the purpose of this study, the scope of a deductible amount will be limited to an amount that is deductible in terms of section $11(\mathrm{a})$.

In terms of section $24 \mathrm{C}(2)$, the following requirements must be complied with in order to utilise the section $24 \mathrm{C}$ allowance:

- The income of any taxpayer, in any year of assessment, must include or consist of an amount received by or accrued to him in terms of any contract; and

- The Commissioner must be satisfied that such amount will be utilised in whole or in part to finance future expenditure; and

- Such future expenditure will be incurred by the taxpayer in the performance of his obligations under such contract.

Section 24C(2) accordingly determines that the allowance is available only if the obligations to perform arise under the same contract as the contract from which the income that must be utilised to finance the future expenditure was received (Davis et al., 2013:24C-2).

The phrase 'will be incurred' in section $24 \mathrm{C}(2)$ creates a definite connection between the incurral of the future expenditure and the taxpayer's performance of his obligations under a contract.

Section $24 C(3)$ stipulates that any deduction allowed in any year of assessment in terms of section $24 \mathrm{C}(2)$ must be included in the income of the taxpayer in the following year of assessment. This means that the section $24 \mathrm{C}$ is a provisional allowance for future expenditure, since it is added back as income in the following year of assessment when the expenditure is actually incurred. This process leads to income and expenditure being matched more evenly.

The Commissioner has, in terms of sections $24 \mathrm{C}(\mathrm{l})$ and (2), the discretion to decide whether the requirements of section $24 \mathrm{C}$ have indeed been complied with, and to subsequently decide on the amount of the deduction. In terms of section 102(1)(b) of the Tax Administration Act No. 28 of 2011 , the burden to prove to the Commissioner that the section 24C allowance should be allowed rests on the taxpayer.

According to Williams (1997:469), the words of section 24C give no guidance as to what the Commissioner can or should take into account before he is 'satisfied' that the requirements of section $24 \mathrm{C}$ are met. He argues that, although income tax cases must traditionally be decided according to the principles laid down in the Act, section $24 \mathrm{C}$ determines that the Commissioner has the discretion to allow the deduction. He also argues that the Commissioner should be able to 
rely on accounting principles as the criteria on which he bases his decision. Williams submits that such an approach will make for much more certainty, consistency and logicality in the granting of the section $24 \mathrm{C}$ allowance. It will, however, be shown in this article that there is enough guidance, other than accounting principles, that the Commissioner can use when applying his discretion.

\section{THE MEANING OF THE WORD 'FUTURE' AND THE PHRASES 'WILL BE INCURRED’ AND 'IN THE PERFORMANCE OF HIS OBLIGATIONS UNDER THE CONTRACT'}

\subsection{Future}

Section $24 \mathrm{C}(1)$ defines 'future expenditure' in relation to any year of assessment and thereby indicates that two or more years of assessment are involved. The phrase 'such year of assessment' refers to the year of assessment in which the taxpayer received the income from the contract and in which the section $24 \mathrm{C}$ allowance will be deducted. The phrases 'future expenditure' and 'will be incurred' are used in conjunction with 'after the end of such year of assessment' in section $24 C(1)$. It follows that the word 'future' indicates that the expenditure in question must be incurred after the end of the year of assessment in which the income is received or accrued or, otherwise stated, in a subsequent year of assessment.

\subsection{Will be incurred}

The word 'incurred' is also used in section 11 , and specifically in section $11(a)$, which refers, inter alia, to expenditure or losses that must be 'actually incurred' in the production of income.

The meanings of the phrase 'actually incurred' and the word 'incurred' have been addressed in several court cases. Some of the court cases also indicate when expenditure has not yet actually been incurred. The following legal precedents have been created in case law:

In Nasionale Pers Bpk v Kommissaris van Binnelandse Inkomste 48 SATC 55 the company wanted to deduct a provision for the future payment of bonuses in terms of section 11 (a). The payment of bonuses was subject to a condition, namely that the employee must still be in the company's employment on 31 0ctober of any given year, in order to receive a bonus. The company's year of assessment ended on 31 March and the company wanted to deduct a pro rata portion of the provision for bonuses in the particular year of assessment.

Hoexter AR held that there was an uncertain future event on 31 March, namely, whether the employee would be in employment on 31 0ctober. This event fell outside the company's year of assessment. The question whether Nasionale Pers Bpk was obligated by law to pay the bonus to a specific employee could only be answered on 31 0ctober. The following legal precedent, as summarised by Williams, was established in this case:

$[P]$ ossible future expenditure which is regarded as merely probable is not deductible in terms of section $11(\mathrm{a})$. Only expenditure in terms of which the taxpayer has taken upon himself an absolute and unconditional liability may be deducted in the relevant tax year (Williams, 2009:436).

Edgars Stores Ltd v Commissioner for Inland Revenue 50 SATC 81 dealt with the deductibility of rental payments for the lease of premises in terms of section $11(\mathrm{a})$. The lease agreement provided 
for basic rental and turnover rental. The amount of turnover rental was based upon the lessee's turnover over a twelve-month period, running from the date of the commencement of the lease. Consequently, the turnover rental was usually only ascertainable subsequent to the concluding date of the lessee's year of assessment. Corbett JA considered the meaning of 'actually incurred', and established the following legal precedent: if a taxpayer has only a contingent liability at the end of the year of assessment, the expenditure is not actually incurred and may not be deducted in the relevant year. Expenditure will be actually incurred only if the taxpayer has an unconditional legal obligation during the year of assessment.

In Ackermans Ltd v Commissioner for South African Revenue Service 73 SATC 1 the company sold its business as a going concern. As part of the purchase price, the purchaser also took over the liabilities, which included contingent liabilities. The purchaser, therefore, paid for the net asset value of the business (the assets less the liabilities). The company contested that, by foregoing a portion of the purchase price of the assets, it incurred expenditure to free itself from the contingent liabilities. The company wanted to deduct the calculated value of the contingent liabilities as 'expenditure actually incurred' in terms of section 11(a). The court disallowed the deduction, as the company did not incur a liability in terms of the sales agreement.

In coming to this conclusion Cloete JA held that:

' $[\varepsilon]$ xpenditure incurred' means the undertaking of an obligation to pay or (which amounts to the same thing) the actual incurring of a liability (Ackermans $L t d v$ Commissioner for South African Revenue Service 73 SATC 1:5).

Binding Class Ruling 029, issued by SARS on 29 May 2011, confirms that a company will not be entitled to a section 11 (a) deduction in respect of contingent liabilities transferred to the company in the course of a section 44 amalgamation transaction. It was ruled that this is notwithstanding any reduction of the purchase price of the business, arising from the buyer assuming such contingent liabilities (SARS, 2011).

In conclusion: the word 'incurred' indicates that the taxpayer has, during the year of assessment, incurred an unconditional obligation to pay for expenditure. The word 'unconditional' means not subject to conditions or stipulations; absolute, unlimited, complete (The Oxford English Dictionary (OED), 2014: unconditional).

The aforementioned cases specifically refer to the meaning of the word 'incurred' as used in section $11(\mathrm{a})$. The word 'incurred' is, however, used in conjunction with the word 'actually' in section $11(a)$. According to the OED the adverb 'actually' merely confirms that the obligation to pay is not only possible or probable at year end, but that the taxpayer has really or in fact incurred the obligation to pay during the year of assessment (OED, 2014: actually).

Section 24C, however, uses the phrase 'will be incurred' and not 'actually incurred'. The Explanatory Memorandum on section $24 \mathrm{C}$ refers to a situation where a taxpayer is taxed on large advance payments not matched by deductible expenditure in the same year of assessment. From the Explanatory Memorandum, it seems that the purpose of section $24 \mathrm{C}$ is to create an allowance that will match the income from the contract with the future deductible expenditure. Section $24 \mathrm{C}(\mathrm{l})$ makes it clear that this allowance represents the expenditure that will be deductible in a year of assessment subsequent to the year of assessment in which the income in terms of the contract is received or accrued.

It is submitted that, based on the meaning of the word 'incurred', the Explanatory Memorandum and section $24 \mathrm{C}(1)$, the phrase 'will be incurred' implies that the taxpayer will have an 
unconditional obligation to pay for expenditure in a subsequent year of assessment. The expenditure is, therefore, not yet incurred but will both be incurred and be deductible in a subsequent year of assessment. The obligation to pay for the expenditure in a subsequent year of assessment must, however, arise from the taxpayer's obligations to perform under the contract.

Paragraph 4.2.1(b) of IN 78 adds to the aforementioned by stating that the phrase 'will be incurred in a subsequent year of assessment' indicates that:

[T] he Commissioner must be satisfied that there is a high degree of probability and inevitability that the expenditure will be incurred by the taxpayer. A taxpayer must, therefore, be able to demonstrate that, although the expenditure is contingent at the end of the year of assessment in question, there is a high degree of certainty that the expense will in fact be incurred in a subsequent year of assessment (SARS, 2014:9).

There must, accordingly, be certainty that the expenditure will be incurred. The fact that there must be a 'high degree of probability and inevitability' in order to obtain certainty is discussed in 6.1 and 7.6 .

\subsection{In the performance of his obligations under the contract}

A 'contract' is defined as an obligatory agreement that comes into existence if the parties intend to create an obligation, provided that all the requirements for the creation of an obligation by agreement are met (Van der Merwe, Van Huyssteen, Reinecke \& Lubbe, 2007:8). The legal concept 'obligation' means a legal tie or bond which binds together legal subjects (persons) (Van der Merwe et al., 2007:2). The content of an obligation consists of both a right to performance by the creditor and a duty to render performance by the debtor (Van der Merwe et al., 2007:2).

In the context of section $24 \mathrm{C}$, the taxpayer who wants to claim a section $24 \mathrm{C}$ allowance has received income from the contract and the taxpayer will, therefore, be the party who has an obligation to render a performance. The taxpayer will, accordingly, be the debtor. The person who paid the income to the taxpayer in terms of the contract will be the creditor, and is the person who has a right to performance.

Section 24C refers, in the plural, to the obligations under the contract. Van der Merwe et al. (2007:311) state that if a contract contains more than one performance, it will give rise to more than one obligation. Every distinguishable performance in terms of the contract, therefore, creates an obligation.

Kellaway (1995:474-475) describes the word 'perform' as: 'giving effect to the obligation created by the contract, whether affirmative or negative', and 'to fulfil a duty created by the contract'. It is thus clear that the obligations created by the contract will be fulfilled only if the taxpayer 'performs'.

According to De Wet and Van Wyk, the divisibility or indivisibility of the performance in terms of the contract is of importance. The two considerations that should be taken into account to determine whether a performance is divisible or indivisible are the nature of the performance and the intention of the parties (1992:145). The following example is given by Van der Merwe et al. (2007:313) to describe the difference between a divisible and an indivisible performance: delivery of one horse in terms of a contract is an indivisible performance due to the nature of the object. Delivery of a team of two horses can be physically divided into two performances, but if the intention of the parties is that the two specific horses must be delivered together to fulfil the 
obligation, then the performance is indivisible due to the intention of the parties. According to Van der Merwe et al., when considering the intention of the parties, the test is to determine whether the parties regard the performance as consisting of separate acts or as a single act (2007:13).

Paragraph 4.1.1 of IN 78 states that when a taxpayer wishes to invoke section $24 \mathrm{C}$ he must be able to prove the existence of a contract, the income received or accrued under that contract, the associated performance obligations and the expenditure relating to the performance of those obligations (SARS, 2014:6). IN 78, therefore, confirms the importance of the definite connection that must exist between the taxpayer's performance of his obligations under a contract and the incurral of the future expenditure.

In light of the aforementioned definite connection and because there must be certainty that the future expenditure will be incurred, it infers that there must also be certainty regarding the indivisible performances that will fulfil the obligations created by the contract. It is necessary to determine which indicators can serve to demonstrate that there is certainty regarding the taxpayer's performance of the obligations under a contract.

\section{THE \&FFECT OF CONTRACTUAL TERMS ON THE CERTAINTY OF THE INCURRAL OF FUTURE EXPENDITURE IN THE PERFORMANCE OF OBLIGATIONS UNDER A CONTRACT}

Contracting parties express their intention to create specific obligations in their contract through the use of terms or stipulations (Van der Merwe et al., 2007:278). According to Van Rensburg, Lotz and Van Rhijn (2010:par 427), the terms in a contract are the provisions that the contracting parties use to indicate the nature and details of the performances due by the parties. This can include the manner, the time and the place of performance. Any other stipulations that the parties may agree upon can also be included as terms in the contract. Examples of common contractual terms given by Van der Merwe et al. are: assumption, conditions, time clauses, warranties and exemption clauses (2007:285-297).

Van Huyssteen, Van der Merwe and Maxwell (2010:143) noted that conditions and warranties are special contractual terms in South African law with particular content and specific consequences. These contractual terms may possibly affect the certainty that the taxpayer will perform his obligations under the contract and are subsequently discussed.

\subsection{Conditional obligations to perform under a contract}

A condition is a term that qualifies the contractual obligation (Van der Merwe et al., 2007:287). Van der Merwe et al. explain that conditions make the operation and consequence of the obligation dependent on an uncertain future event that will either happen or not. Uncertainty is, therefore, an indispensable element of a conditional obligation (De Wet \& Van Wyk, 1992:149). An obligation that is suspended by a condition cannot be enforced until the fulfilment of the condition and, therefore, cannot be validly performed (Van der Merwe et al., 2007:293). This implies that the conditions in a contract influence the certainty as to whether the obligations will be performed. Conditions contained in a contract must, therefore, be considered when determining whether the performance of the obligations in the contract will lead to the incurral of future expenditure. 
In Nasionale Pers Bpk v Kommissaris van Binnelandse Inkomste 48 SATC 55 (refer to 5.2) it was shown that when there is a condition, the expenditure is only probable and not absolute and the expenditure is accordingly not 'actually incurred' and not deductible in terms of section 11 (a). It is submitted that the same principle laid down in Nasionale Pers Bpk $v$ Kommissaris van Binnelandse Inkomste 48 SATC 55 should be applicable when interpreting section 24C. The effect of conditions in the contract is that the performance of the obligations under the contract as well as the related incurral of future expenditure are subject to the occurrence of an uncertain future event. Accordingly, neither the performance nor the incurral of the expenditure is absolute and certain.

Paragraph 4.2.1(b) of IN 78 confirms the aforementioned and refers to the fact that there must be, inter alia, a high degree of inevitability that the expenditure will be incurred by the taxpayer (SARS, 2014:8). The word 'inevitable' is described in the 0ED as:

That cannot be avoided; not admitting of escape or evasion; unavoidable. In extended use: that cannot fail or is bound to occur, appear, be used, etc.; that is inherent (in) or naturally belongs to (OED, 2014: inevitable).

In the context of section 24C, the word 'inevitable' indicates that the incurral of the expenditure in a subsequent year of assessment cannot be avoided. It is submitted that if a taxpayer can prove that there are no conditions in a contract and that he therefore has an unconditional obligation to perform and that this performance will lead to the incurral of expenditure, then such expenditure will be inevitable.

It is, accordingly, argued that the absence of conditions in a contract (an unconditional obligation to perform under a contract) can be an indicator that the taxpayer will be able to prove that expenditure will be incurred in the performance of his obligations under a contract in the subsequent year of assessment. This is assuming that there are no other contractual terms or other circumstances that affect the certainty of either the taxpayer's obligation to perform under the contract or the related incurral of future expenditure.

Maintenance and repair contracts often contain conditional obligations to perform. Paragraph 4.2.6 of IN 78 makes it clear that it is not possible to formulate a general rule for the treatment of maintenance obligations under section 24C. IN 78 explains that, if maintenance under a contract is required only if something breaks, the Commissioner will not be satisfied that the future expenditure will be incurred (SARS, 2014:15). It is submitted that this is because the obligation to perform is conditional and therefore uncertain. IN 78, however, states that if a maintenance contract is, for example, a vehicle service plan under which certain maintenance must be performed at regular intervals, the Commissioner will be satisfied that the future expenditure will be incurred. This is assuming that the client makes the vehicle available for the maintenance to be performed (SARS, 2014:15).

\subsection{Warranties included in a contract}

Van Rensburg et al. (2010:par 447) describe a warranty as 'a contractual undertaking by a debtor that a certain fact relating to his or her performance is or will be as it is stated or promised to be'. Van Rensburg et al. further state that, in the case of a warranty, the debtor promises to make good any loss suffered by the creditor due to the fact that the debtor's performance did not realise as warranted. In the context of section $24 \mathrm{C}$, this implies that a warranty in a contract from which a taxpayer received income can, therefore, also lead to the incurral of future expenditure in the performance of the taxpayer's obligations under a contract. 
In the context of section $24 \mathrm{C}$, the effect of a warranty in a contract can be explained by the following example. In terms of a sales contract, a taxpayer receives R1 000 from a client and must provide a product to the client. The sales contract also contains a warranty regarding the quality of the product, stating that if the product is defective the client can return the product and the taxpayer will replace it with a new product. Assume that the product has already been delivered during the year of assessment, but the warranty is valid for a period that continues after the end of the year of assessment. The taxpayer will know whether he is liable for damages only when the creditor indicates that the product is defective. Until the latter event occurs, the taxpayer will not know whether he is liable for damages and, accordingly, whether he will have to perform under the warranty in the contract.

In both ITC 152754 SATC 227 and ITC 160158 SATC 172 a warranty was included in the contract from which the taxpayers received income. The court confirmed the aforementioned argument regarding the effect of warranties in a contract on the certainty that future expenditure will be incurred in the performance of the taxpayers' obligations under a contract, and disallowed the section 24C allowance.

Paragraph 4.2.5 of IN 78 also confirms that contracts under which advance income was received might contain a warranty against defective workmanship or materials supplied. In the event that the taxpayer is required to correct deficiencies under a warranty, he may have to incur expenditure. IN 78 confirms that the section $24 \mathrm{C}$ allowance will not be available in the event of a warranty claim because the event which potentially gives rise to the warranty claim is contingent and not only dependent on the customer returning the item (SARS, 2014:14-15).

From the aforementioned it is therefore submitted that a warranty in a contract is an indicator that shows there is uncertainty regarding both the taxpayer's performance of his obligation under the contract and the incurral of the related future expenditure.

\subsection{Time clauses included in a contract}

If there is a term in the contract that relates to an event that is certain, but the timing of the event is uncertain, then it is not a condition, but a time clause (De Wet \& Van Wyk, 1992:149). Van Huyssteen et al. (2010:142) state that if the parties to a contract contemplate a certain moment or event in the future as a qualification, it is a time clause, as opposed to a condition, even though it is uncertain when it will occur.

If a contract contains a time clause, it therefore regulates the time of the performance and indicates when the performance must be rendered. The contract can refer to a specific date on which the performance must be rendered. The contract can also refer to an event that is certain to happen, and state that when this event occurs, the performance must be rendered. In the context of section $24 \mathrm{C}$ it is submitted that when parties insert a time clause in a contract, their intention is not to make their performance subject to the occurrence of an uncertain future event, but rather to ensure that both parties have certainty and agree that the event will happen at a specific time. A time clause, therefore, indicates that there is certainty that future expenditure will be incurred in the performance of the taxpayer's obligations under the contract. 


\section{OTHER CIRCUMSTANCES THAT INDICATE WHETHER THERE IS CERTAINTY THAT THE FUTURE EXPENDITURE WILL BE INCURRED}

The Tax Courts have also considered circumstances other than the contractual terms in the contract when determining the deductibility of the section $24 \mathrm{C}$ allowance. It should, therefore, be considered which of these other circumstances affect the certainty of the incurral of future expenditure in the performance of a taxpayer's obligations under the contract.

\subsection{A contingent liability to pay for expenditure}

A conditional obligation to perform under a contract (refer to 6.1) must be distinguished from a contingent liability to pay for expenditure.

The nouns 'obligation' and 'liability' can be used as substitutes for each other, since an 'obligation' refers to a liability incurred (OED, 2014: obligation) and a 'liability' refers to an obligation itself (Bird, 1983: liability). The adjectives 'conditional' and 'contingent' can also be used as substitutes for each other. 'Conditional' is described as not absolute (OED, 2014: conditional) and dependent upon the happening of a future and uncertain event (Bird, 1983: condition). 'Contingent' is described as conditional or not absolute (OED, 2014: contingent) or dependent upon the happening of an event (Bird, 1983: contingent). It is, therefore, submitted that the phrase 'conditional obligation' is similar to the phrase 'contingent liability'.

It was held in Ackermans Ltd v Commissioner for South African Revenue Service 73 SATC I (refer to 5.2) that, in the context of section $11(a)$, when reference is made to the incurral of a liability it also means an obligation to pay for expenditure. When the phrase 'contingent liability' is used in case law on section 11 (a) it often refers to the liability to pay for expenditure which is contingent as opposed to expenditure that is 'actually incurred'. Further, as shown in 5.2, when a taxpayer has only a contingent liability to pay for expenditure, the expenditure will not be 'actually incurred' and will, therefore, not be deductible under section 11 (a). In addition to a contingent liability not being deductible under section $11(\mathrm{a})$, section $23(\mathrm{e})$ also expressly prohibits the deduction of any income carried to any reserve fund. De Koker and Williams (2011:par 7.10) confirm that a contingent liability is an example of a deduction prohibited by section $23(\mathrm{e})$. They, however, state that section $24 \mathrm{C}$ is an exception to section $23(\mathrm{e})$, as it permits the deduction of 'future expenditure' on contracts (2011:par 7:47). It should, however, be noted that it is not the contingent liability itself that is deductible under section $24 \mathrm{C}$. The section $24 \mathrm{C}$ allowance is based on the unconditional obligation to perform under the contract which must lead to the incurral of future expenditure.

The phrase 'contingent liability' was used in connection with section 24C in ITC 160158 SATC 172. It, however, caused confusion, as the context in which the phrase was used was not clearly explained. The appellant (the taxpayer) carried on the business of process control engineering. This entailed the sale of computer hardware and measuring instruments. The taxpayer also serviced the hardware, instruments and programs by setting them up to meet the specific requirements of each client. The standard conditions of offer and sale (the contract) contained a warrant against defective workmanship and materials supplied. It was, however, specified that the supply of the manufactured goods carried the manufacturer's warranty and that the taxpayer was not responsible for replacing these goods at his own expense. 
The sales price of the goods and service included a profit margin to cover cost likely to be incurred in terms of the warranty in the contract. The taxpayer presented evidence to demonstrate that almost all the contracts required after-sales maintenance, rectification and fine-tuning. This was due to the technical nature of the installations.

The taxpayer deducted an allowance under section $24 \mathrm{C}$ in his tax return. He argued that provision was made in the sales price to cover future expenditure that would be incurred in the performance of his obligations under the contract. According to the Commissioner, the taxpayer had only a contingent liability and, therefore, the section $24 \mathrm{C}$ allowance was not allowed. The taxpayer objected to the assessment and the Tax Court had to review the administrative discretion exercised by the Commissioner.

In delivering his judgment, Van Niekerk J held, inter alia, that he agreed that the Commissioner could not be satisfied that expenditure would be incurred if there was only a contingent liability. Both the Commissioner and Van Niekerk J, therefore, used the phrase 'contingent liability' without explaining whether they referred to a contingent liability to pay for expenditure or to a contingent liability to perform under the contract. Clegg and Stretch criticised the judgment in ITC 160158 SATC 172 and stated that:

If expenditure is not contingent, then there will be no need for the section, as the liability would be absolute and a deduction under section 11 (a) could be claimed. The wording requires the Commissioner to be satisfied that expenditure 'will be incurred after the end of such year', making it clear that it is the incurral itself which arises thereafter, and which must, by definition, be uncertain and contingent as at the end of the year in question. It is submitted that there must be in existence an enforceable and uncontingent [unconditional] obligation to perform under a contract, which performance will lead to the incurral of expenditure (2011:par 11.11.7).

Clegg and Stretch, accordingly, explain that if the liability was not contingent at the end of the year of assessment, it would be actually incurred. The taxpayer would, therefore, have claimed a deduction under section $11(\mathrm{a})$ and there would be no need for section 24C. Clegg and Stretch, therefore, correctly point out that it is the taxpayer's obligation to perform under a contract which must serve as the indicator as to whether there is certainty that future expenditure will be incurred, and not the liability to pay for the expenditure.

The interplay between the accounting and tax treatment of a contingent liability can be explained as follows:

For tax purposes, an amount can be classified as a contingent liability because it is not yet 'actually incurred' and it will therefore not be deductible under section 1 l(a). The same amount might, however, meet the definition of a provision for accounting purposes according to IAS 37 and must be recognised as a provision (a reserve) in the financial statements. Such provision, which is a contingent liability for tax purposes, can however be allowed as a deduction in terms of section $24 \mathrm{C}$ if it meets all the requirements of section 24C. The section $24 \mathrm{C}$ allowance can, therefore, in certain circumstances be equal to, or similar to, an accounting provision. However, the existence of a contingent liability to pay for expenditure is not an indicator as to whether there is certainty that future expenditure will be incurred in the performance of the obligation under the contract. 


\subsection{Definite connection between the incurral of expenditure and the obligation to perform under the contract}

A definite connection must exist between the incurral of the future expenditure and the taxpayer's performance of his obligations under a contract (refer to 5.2). ITC 152754 SATC 227 confirmed this principle. The appellant (the taxpayer) carried on the business, inter alia, of a furniture dealer under the slogan 'your two year guarantee store'. Approximately $80-85 \%$ of the taxpayer's sales were affected through instalment sale agreements (sale contracts). The sale contracts did not contain any reference to a guarantee. A guarantee was, however, provided to the purchaser by means of a separate document. The taxpayer utilised the section $24 \mathrm{C}$ allowance by including various general overhead expenditure in his section $24 \mathrm{C}$ allowance, stating that he had to incur this expenditure in order to service the two-year sale contracts. Melament J stated that the taxpayer could not provide evidence that the sale contacts imposed any obligation on him in respect of the overhead expenditure in question. It was further held that the obligation under the guarantee was a separate contract, and thus not an obligation under the sale contracts.

It is, therefore, submitted that the absence of a definite connection between the incurral of the future expenditure and the taxpayer's performance of his obligations under a specific contract is an indicator that there is not certainty that future expenditure will be incurred by the taxpayer in the performance of his obligations under that contract.

\subsection{The directors' discretion}

In ITC 169763 SATC 146 the appellant (the taxpayer) was a share block company, operating a timeshare consisting of flats. A Use Agreement (the contract) existed between the taxpayer on the one hand and each member that acquired a share block, on the other hand. Each member was bound in terms of his/her individual Agreement of Sale to this one contract. The contract determined that the members were required to pay levies to the taxpayer and the taxpayer had certain obligations that he had to fulfil, including the repair, upkeep, renovation, control, management and administration of the company, the property and the immovable property, including all the flats. The performance of these obligations was, however, left to the discretion of the directors of the company.

The Commissioner disallowed the section $24 \mathrm{C}$ allowance and stated, inter alia, that the incurral of the future expenditure was left to the discretion of the directors and, therefore, the obligation to incur future expenditure did not arise from the contract. Galgut J, however, held that the contract was an on-going agreement, which created a set of rights and obligations which would arise in each and every year. He stated that the fact that the directors had the discretion to provide for whatever became necessary to maintain or replace the fixed or immovable property did not change the fact that it was the contract that determined the taxpayer's obligations to perform. Although the contract did not specify the quantum of the future expenditure, the directors had the discretion to decide when and how the obligations would be fulfilled. The directors presented a detailed budget, indicating what the necessary maintenance, renovations or the replacement of movable property was and, accordingly, how much the related expenditure would be. The court allowed the taxpayer to deduct the section 24C allowance.

From the aforementioned it is clear that when the directors have the discretion to bring to affect the taxpayer's obligations it is not an indication that there is uncertainty regarding the taxpayer's 
obligations to perform in terms of the contract but that it is rather an indicator that there is certainty that the future expenditure will be incurred.

\subsection{Quantifiability of future expenditure}

Section $24 \mathrm{C}$ provides for the deduction of an allowance for future expenditure as opposed to a deduction for expenditure actually incurred (in terms of section $11(\mathrm{a})$ ). Unless the contract quantifies the exact amount of future expenditure to be incurred by the taxpayer, the taxpayer will not know what the exact amount of the future expenditure will be until it is actually incurred. In ITC 160158 SATC 172 (refer to 7.1), Van Niekerk J stated that 'there must be a clear measure of certainty as to whether the expenditure in contention is quantified or quantifiable' in order to allow the section $24 \mathrm{C}$ allowance. He further stated that 'since a deduction is sought, this must arise from an obligation and must be quantifiable'.

Commissioner for Inland Revenue $v$ Edgars Stores Ltd 48 SATC 89 dealt with the deductibility of expenditure in terms of section 11 (a). It was held that if an unconditional liability was incurred, but it cannot be quantified, then the amount must be estimated based on available information and claimed in that tax year. The deduction in terms of section $11(a)$, therefore, does not depend on whether the amount is already quantified. If a reliable estimate of the expenditure can be made, then the deduction should be allowed.

It is argued that the same principle laid down in Commissioner for Inland Revenue $v$ Edgars Stores $L t d 48$ SATC 89 should apply in the case of section 24C. When an enforceable and unconditional obligation under a contract exists and there is certainty that the performance of this obligation will lead to the incurral of expenditure, the amount must be estimated if it is not already quantified in the contract.

From ITC 169763 SATC 146 (refer to 7.3) it is also clear that if a contract does not specify the quantum of the expenditure that the taxpayer must incur in order to fulfil his obligation under the contract, the amount of the allowance can still be quantified based on a fair and reasonable estimate. The aforementioned case, however, clearly shows that these estimates should be detailed and they should correlate with the specific obligation that the taxpayer has under the contract. As was shown in ITC 152754 SATC 227 (refer to 7.2), it is clear that the Commissioner must be satisfied that this amount is not based only on vague allocations of expenditure.

Paragraph 5.1 of IN 78 confirms the aforementioned. It gives examples and guidance regarding the calculation of the amount of the section $24 \mathrm{C}$ allowance. It states that the taxpayer must base the determination of the amount of future expenditure on fair and reasonable estimates which take into account the last available information. It also states that the calculation must contain sufficient detail to demonstrate that the expenditure included in the calculation results from the future performance of obligations under the contract. Further, the Commissioner must be able to review and audit the calculation (SARS, 2014:18).

From the aforementioned it is submitted that unquantified future expenditure to be incurred in terms of a contract will not indicate that the incurral of the future expenditure is uncertain. If the taxpayer has an unconditional obligation to perform under a contract and the amount is quantifiable, the section $24 \mathrm{C}$ allowance will be deductible (provided all other requirements of section 24 ( are met). 


\subsection{Collective conditional obligations}

In Special Board Decision No. 129 the appellant (the taxpayer) sold policies and earned commission on all his sales. The taxpayer had an obligation to refund the commission if the policies were cancelled within two years. The taxpayer estimated his expected obligation to refund the commission, based on the cancellation history, and deducted a section $24 \mathrm{C}$ allowance for this future expenditure from the commission income received.

The Commissioner disallowed the deduction, stating that he was not satisfied that the amount would necessarily be incurred by the taxpayer in the performance of his obligations under the contract. Rosenberg, the Chairman of the Board, held that the expected obligation was only a contingent liability and that the obligation to refund the commission had not yet vested. It was also held that the fact that reliable data was available to enable a reasonably accurate projection of cancellation figures did not change the character of the obligation. The obligation of the taxpayer remained contingent in relation to each individual policy. The section $24 \mathrm{C}$ allowance was, accordingly, not allowed.

This decision is similar to what was held in Nasionale Pers Bpk $v$ Kommissaris van Binnelandse Inkomste 48 SATC 55 (refer to 6.1). The taxpayer also contested that the expenditure that related to the payment of the bonuses could be distributed amongst the entire population of employees and that the expenditure was an inevitable commercial reality. Hoexter AR, however, held that Nasionale Pers Bpk could not rely on a collective obligation to pay bonuses, as the company had concluded obligations with each individual employee and each individual contract was subject to a condition.

Paragraph 7.1 of IN 78 makes it clear that, before the section 24 C allowance will be allowed, every individual contract should meet the section $24 \mathrm{C}$ requirements on its own merit. It does, however, state that it may be difficult to determine the future expenditure and link it to a particular contract in certain circumstances. In such circumstances, if the contracts are similar and the taxpayer has the same unconditional obligation to perform under all those contracts, the contracts may be grouped together in order to perform the analysis of the future expenditure at a higher level by taking a number of contracts into consideration (SARS, 2014:24-25).

It is, therefore, submitted that in the event that a taxpayer is involved in several similar contracts containing similar conditional obligations, the contracts cannot be grouped together to determine the probability that the future expenditure will be incurred. The probability that collective conditional obligations to perform will realise is, therefore, not an indicator that future expenditure will be incurred. Each contract and its related obligations to perform should meet the requirements of section $24 C$ on their own merit.

\subsection{Probability of performance}

According to paragraph 4.2.1(b) of IN 78, the phrase 'will be incurred in a subsequent year of assessment' indicates that there must be a high degree of probability and inevitability that the expenditure will be incurred by the taxpayer (SARS, 2014:8). It was shown in 6.1 that the word 'inevitability' refers to the fact that the taxpayer has an unconditional obligation to perform under the contract. IN 78 further states that when the taxpayer's performance under a contract is unconditional, but is dependent on the customer taking action, the obligation to perform remains unconditional. However, the probability that the customer will take action must be considered (SARS, 2014:9). 
According to IN 78, a taxpayer might have a legal obligation to perform under a contract, but at a certain point in time, the Commissioner might no longer be satisfied that the obligation will ever be performed. IN 78 uses gift vouchers as an example. If a taxpayer receives income when selling a gift voucher, he has an unconditional obligation to perform in terms of the gift voucher, but the performance is dependent on the customer redeeming the gift voucher. According to IN 78, historical data can show, for example, that if a gift voucher is not redeemed in two years it will never be redeemed. In such circumstances, the Commissioner will, after two years, not be satisfied that it is probable that the taxpayer will incur future expenditure and, therefore, the section $24 \mathrm{C}$ allowance will not be allowed again. In the event that the incurral of the future expenditure is not probable, the required degree of certainty that the expenditure will be incurred will, accordingly, also not be met (SARS, 2014:10).

The concept of probability, with specific reference to the probability that the customer will take action is, therefore, also an indicator which can serve to demonstrate whether the taxpayer will perform his unconditional obligation under the contract and whether the related future expenditure will be incurred.

In terms of IN 78 there must be a high degree of probability and inevitability as well as a high degree of certainty that the expenditure will be incurred in a subsequent year of assessment (SARS, 2014:8-9). Exactly what is meant by 'high degree' and how it should be measured are not explained in IN 78. It is argued that, in the context of section 24C, 'a degree of certainty' can, inter alia, refer to the level of confidence that a taxpayer or the Commissioner has that the expenditure will be incurred in a subsequent year of assessment. A 'high degree' will accordingly refer to a high level of such confidence. It is, however, argued that the measurement of this 'high degree' can easily become subjective and, therefore, SARS should provide objective guidelines regarding the determination of a 'high degree'.

\section{CONCLUSION}

Section 24 provides for an allowance in respect of future expenditure that will be incurred by the taxpayer in the performance of his obligations under a contract from which the taxpayer derived income. In order to claim the allowance there must, inter alia, be certainty regarding the performance of the obligations under the contract as well as regarding the incurral of the future expenditure. The first objective of this article was to compile a list of indicators demonstrating when there is certainty that future expenditure will be incurred by the taxpayer in the performance of his obligations under the contract. The second objective was to determine whether the guidance provided by IN 78 regarding the aforementioned is in agreement with previous established principles. The following indicators regarding the certainty that future expenditure will be incurred were identified:

1. If there is certainty that the taxpayer will perform his obligations under the contract, it will indicate that there is certainty regarding the incurral of the related future expenditure.

Each indivisible performance required to fulfil the obligations under the contract must be identified on its own in order to determine whether it will lead to the incurral of future expenditure.

2. The absence of a definite connection between the incurral of the future expenditure and the taxpayer's performance of his obligations under a contract is an indicator that there is not 
certainty that future expenditure will be incurred by the taxpayer in the performance of his obligations under a contract.

3. Contractual terms regulate the performance of the contracting parties. Conditions and warranties are contractual terms that indicate that there is uncertainty regarding the taxpayer's performance of his obligations under the contract.

The absence of conditions or warranties in a contract or the inclusion of a time clause in a contract can indicate that there is certainty regarding the taxpayer's performance of his obligations under the contract.

The discretion of directors to bring to affect the taxpayers' unconditional obligation to perform under a contract is an indication of certainty regarding the incurral of the future expenditure.

The aforementioned indicators show that the incurral of the future expenditure is inevitable.

4. To attain the required degree of certainty that future expenditure will be incurred, the taxpayer must be able to prove the probability that he will perform the unconditional obligation under the contract.

The probability of the taxpayer's performance can be determined with reference to historical data, and it is accordingly an indicator that will serve to demonstrate whether there is certainty that future expenditure will be incurred by the taxpayer in the performance of his obligations under the contract.

Regarding the certainty of the incurral of the future expenditure it was found that:

1. A contingent liability of the taxpayer to incur expenditure in the pursuance of the performance of his obligation under the contract is not an indicator as to whether there is certainty that future expenditure will be incurred. Reference must rather be made to the taxpayer's obligation to perform under a contract as an indicator as to whether there is certainty that future expenditure will be incurred.

2. Unquantified future expenditure that will be incurred in terms of a contract will not indicate that the incurral of the future expenditure is uncertain. An estimate of the amount of future expenditure that will be incurred must be based on fair and reasonable grounds.

3. A taxpayer cannot group similar contracts with similar conditional obligations to perform together in order to determine the probability, and thus the certainty, that future expenditure will be incurred in the performance of the taxpayer's obligations under a contract.

4. Apart from the probability indicator provided for by IN 78, no other new guidelines relating to the certainty of the incurral of future expenditure which were not previously underlined in Tax Court cases on section $24 \mathrm{C}$ are provided in IN 78. IN 78 refers to a high degree of probability, inevitability and certainty that the expenditure will be incurred in a subsequent year of assessment (SARS, 2014:8-9). Exactly what is meant by 'high degree' and how it should be measured are not explained in IN 78, and it is suggested that objective guidelines to determine a 'high degree' should be provided by SARS. 


\section{LIST OF REFERENCES}

Ackermans Ltd v Commissioner for South African Revenue Service, 2010 (1) SA (1) SCA, 73 SATC 1.

Bird, R. (1983). Osborn's Concise Law Dictionary. London: Sweet \& Maxwell.

Clegg, D. \& Stretch, R. (2011). Income Tax in South Africa. Electronic Addition. Updated: March 2011. LexisNexis. Available:

http://www.lib.sun.ac.za.ez.sun.ac.za/nxt/gateway.dll/7b/6d?f=templates $\$ f n=$ default.htm $\$ v i d=m y l$ nb:10.1048/enu. (Accessed 15 May 2014).

Caltex Oil (SA) Ltd v Commissioner of Inland Revenue, 1975 (1) SA 665 (A), 37 SATC 1

Commissioner for Inland Revenue v Edgars Stores Ltd, 1986 (4) SA 312(T), 48 SATC 89.

Davis, D., Olivier, L. \& Urquhart, G. (2013). Juta's income tax - Volume 1. Updated: Revision 18, 2013.

Claremont: Juta and Company Ltd.

De Koker, A.P. \& Williams, R.C. (2011). Silke on South African Income Tax. Electronic Edition. Updated: June 2011. LexisNexis. Available:

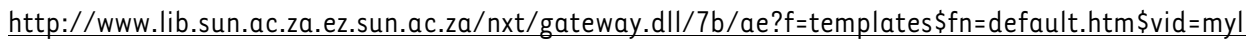
nb:10.1048/enu. (Accessed 15 May 2014).

De Wet, J.C. \& Van Wyk, A.H. (1992). Die Suid-Afrikaanse Kontrakreg en Hande/sreg. Durban: Butterworth.

Edgars Stores Ltd v Commissioner for Inland Revenue, 1988 (3) SA 764 (A), 50 SATC 81.

IAS 1, Presentation of Financial Statements. (2003). International Accounting Standards Board (IASB). London: IFRS Foundation Publication Department. (2014).

IAS 37, Provisions, Contingent Liabilities and Contingent Assets. (1998). Internationa/ Accounting Standards Board (IASB). London: IFRS Foundation Publication Department. (2014).

ITC 1527, 1991, 54 SATC 227.

ITC 1601, 1995, 58 SATC 172.

ITC 1667, 1999, 61 SATC 439.

ITC 1697, 1999, 63 SATC 146.

ITC 1739, 2002, 65 SATC 43.

Kellaway, દ.A. (1995). Principles of Legal Interpretation. Durban: Butterworth.

Meyerowitz, D. Meyerowitz on Income Tax (2007 - 2008 Edition). Cape Town: The Taxpayer.

Nasionale Pers Bpk v Kommissaris van Binnelandse Inkomste, 1986 (3) SA 549 (A), 48 SATC 55.

Olivier, L. (2007). Tax implications of the sale of a business. SA Law Journal, 124(3):600-617.

Port Elizabeth Electric Tramway Co Ltd v Commissioner for Inland Revenue, 1936 CPD 241, 8 SATC 13.

SARS. (1980). Explanatory Memorandum on the Income Tax Bill, 1980. Available:

http://www.osall.org.za/docs/2011/02/1980-IT-Bill.pdf. (Accessed 15 May 2014). 
SARS. (2011). Binding Class Ruling 029, Deductibility of Contingent Liabilities taken over when buying the assets and liabilities of another company within the same group of companies. Available: http://www.sars.gov.za/AllDocs/LegalDoclib/Rulings/LAPD-IntR-R-BCR-2012-29\%20\%20Deductibility\%20Contingent\%20Liabilities\%20Taken\%200ver.pdf (Accessed 19 June 2015) SARS. (2014). Interpretation Note: No. 78, Allowance for future expenditure on Contracts. Available: http://www.sars.gov.za/AllDocs/LegalDoclib/Notes/LAPD-IntR-IN-2014-03\%20\%20IN78\%20Allowance\%20for\%20Future\%20Expenditure\%20on\%20Contracts.pdf. (Accessed 30 July 2014).

Stiglingh, M., Koekemoer, A., Van Schalkwyk, L., Wilcocks, J. \& De Swardt, R. (2014). S/LKE: South African Income Tax 2014. Durban: LexisNexis.

South Africa. (1962). Income Tax Act, Act 58 of 1962. Pretoria: Government Printer.

South Africa. (2011). Tax Administration Act No. 28 of 2011. Pretoria: Government Printer.

Special Board Decision No. 129, 23 November 1999, South African Tax Cases; Case No. 107232003 (1) JTLR I (GSpCrt).

The Oxford English Dictionary. (2014). Available: http://www.oed.com/. (Accessed 15 May 2014).

Van der Merwe, S.W.J., Van Huyssteen, L.F., Reinecke, M.F.B. \& Lubbe, G.F. (2007). Contract: General Principles. Juta and Company Ltd.

Van Huyssteen, L.F., Van der Merwe, S.W.J. \& Maxwell C.J. (2010). Contract Law in South Africa. The Netherlands: Kluwer Law International BV.

Van Rensburg, A.D.J., Lotz, J.G. \& Van Rhijn, T.A.R. (2010). Law of South Africa, 5(1):par370-508. Available:

http://www.lib.sun.ac.za.ez.sun.ac.za/nxt/gateway.dll?f=templates $\$ f n=d$ efault.htm $\$ v i d=m y l n b: 10$. 1048/enu. (Assessed 15 May 2014).

Williams, R.C. (1997). Allowance under the Income Tax Act for Expenditure Probably to Be Incurred under a Contract in a future Year. SA Law Journal, 114, pp. 464-470.

Williams, R.C. (2009). Income Tax in South Africa Cases \& Material, $3^{\text {td }}$ edition. Durban: LexisNexis. 